Section Editor

John J. Millichap, MD

Teaching NeuroImages:

\title{
Three complications of small-cell lung cancer involving the brain
}

Oliver Neuhaus, MD

Gabriele Käfer, MD

Correspondence to

Dr. Neuhaus:

o.neuhaus@klksig.de
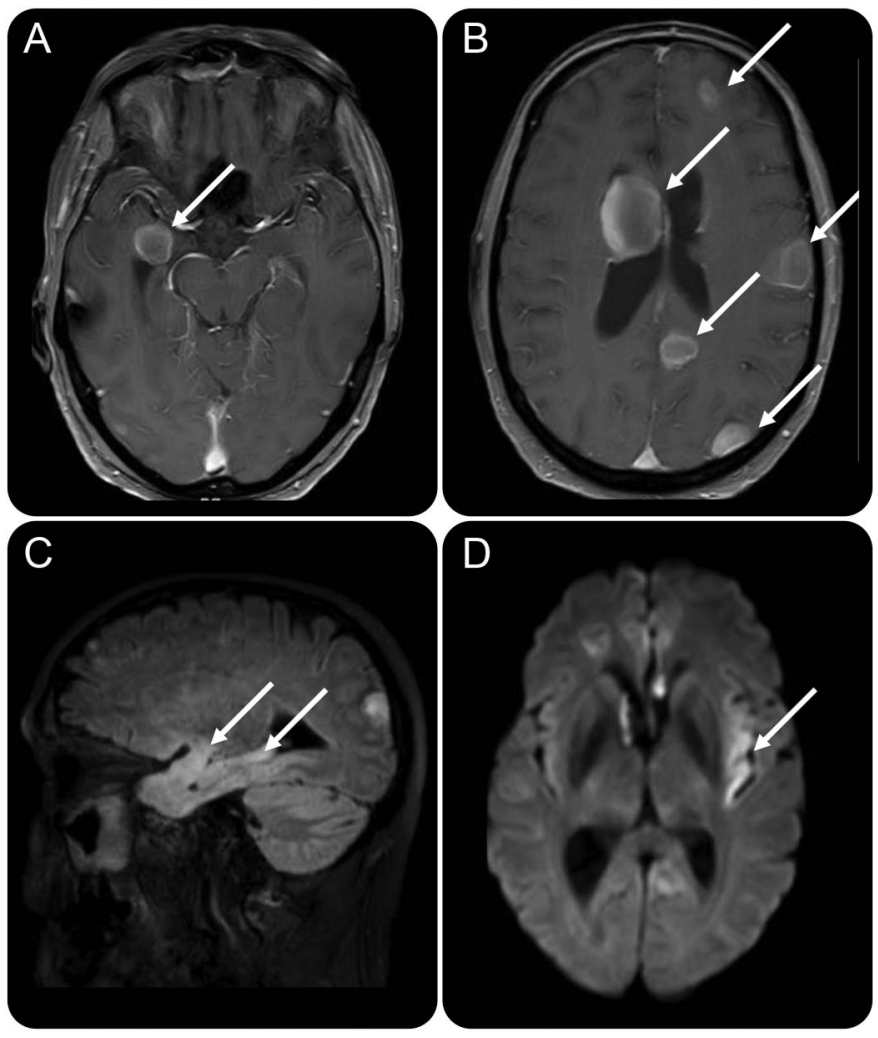

(A, B) Postcontrast T1-weighted axial MRI shows multiple gadolinium-enhancing brain metastases (arrows). (C) Sagittal fluid-attenuated inversion recovery image; arrows show hyperintense lesions at the mesiotemporal cortex and other parts of the limbic system. (D) Axial diffusion-weighted image; arrow shows reduced diffusion at the left peri-insular region.

A 53-year-old man with small-cell lung cancer (SCLC) with brain metastases presented with acute hyperthermia (up to $39^{\circ} \mathrm{C}$ ) without evidence of infection, aphasia, and 2 generalized epileptic seizures. MRI made 3 brain complications of SCLC visible. First, multiple brain metastases (figure, $\mathrm{A}$ and $\mathrm{B}$ ) were noted. Second, hyperintense areas at the limbic system (figure, C) were present, favoring a diagnosis of paraneoplastic limbic encephalitis, although associated antibodies were negative. Limbic encephalitis can cause both hyperthermia and seizures. ${ }^{1}$ Third, aphasia was explained by a region of reduced diffusion at the left insula (figure, D). Consistently, CSF analysis confirmed leptomeningeal carcinomatosis.

\section{AUTHOR CONTRIBUTIONS}

Both authors were involved in clinical care and investigative workup of the patient. Dr. Neuhaus conceived and designed the study and developed and wrote the neurology part of the manuscript. Dr. Käfer wrote the oncology part and revised the manuscript.

\section{STUDY FUNDING}

No target funding reported.

\section{DISCLOSURE}

The authors report no disclosures relevant to the manuscript. Go to Neurology.org for full disclosures.

\section{REFERENCE}

1. Dalmau J, Rosenfeld MR. Paraneoplastic syndromes of the CNS. Lancet Neurol 2008;7:327-340.
Download teaching slides: Neurology.org 


\section{Neurology}

\section{Teaching NeuroImages: Three complications of small-cell lung cancer involving the brain}

Oliver Neuhaus and Gabriele Käfer

Neurology 2017;89; 40

DOI 10.1212/WNL.0000000000004150

This information is current as of July 24,2017

Updated Information \&
Services
Supplementary Material

References

Subspecialty Collections

Permissions \& Licensing

Reprints including high resolution figures, can be found at: http://n.neurology.org/content/89/4/e40.full

Supplementary material can be found at: http://n.neurology.org/content/suppl/2017/07/24/WNL.0000000000004 150.DC1

This article cites 1 articles, 0 of which you can access for free at: http://n.neurology.org/content/89/4/e40.full\#ref-list-1

This article, along with others on similar topics, appears in the following collection(s):

Metastatic tumor

http://n.neurology.org/cgi/collection/metastatic_tumor Paraneoplastic syndrome

http://n.neurology.org/cgi/collection/paraneoplastic_syndrome

Information about reproducing this article in parts (figures,tables) or in its entirety can be found online at:

http://www.neurology.org/about/about_the_journal\#permissions

Information about ordering reprints can be found online:

http://n.neurology.org/subscribers/advertise

Neurology ${ }^{\circledR}$ is the official journal of the American Academy of Neurology. Published continuously since 1951, it is now a weekly with 48 issues per year. Copyright () 2017 American Academy of Neurology. All rights reserved. Print ISSN: 0028-3878. Online ISSN: 1526-632X.

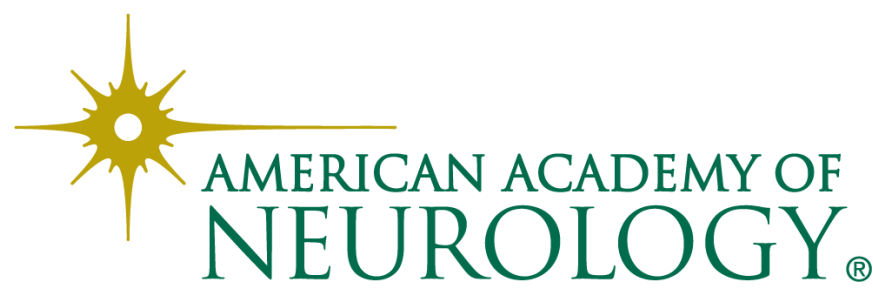

